\title{
Variability of throughfall quantity in a mixed evergreen-deciduous broadleaved forest in central China
}

\author{
Lei $\mathrm{Su}^{1,2}$, Zongqiang $\mathrm{Xie}^{1 *}$, Wenting $\mathrm{Xu}^{1}$, Changming Zhao ${ }^{1}$ \\ ${ }^{1}$ State Key Laboratory of Vegetation and Environmental Change, Institute of Botany, Chinese Academy of Sciences, Beijing 100093 , \\ China. \\ ${ }^{2}$ International Joint Research Laboratory for Global Change Ecology, School of Life Sciences, Henan University, Kaifeng, Henan 475004, \\ China. \\ * Corresponding author. E-mail: xie@ibcas.ac.cn
}

\begin{abstract}
Mixed evergreen-deciduous broadleaved forest is the transitional type of evergreen broadleaved forest and deciduous broadleaved forest, and plays a unique eco-hydrologic role in terrestrial ecosystem. We investigated the spatiotemporal patterns of throughfall volume of the forest type in Shennongjia, central China. The results indicated that throughfall represented $84.8 \%$ of gross rainfall in the forest. The mean CV (coefficient of variation) of throughfall was $27.27 \%$. Inter-event variability in stand-scale throughfall generation can be substantially altered due to changes in rainfall characteristics, throughfall $\mathrm{CV}$ decreased with increasing rainfall amount and intensity, and reached a quasi-constant level when rainfall amount reached $25 \mathrm{~mm}$ or rainfall intensity reached $2 \mathrm{~mm} \mathrm{~h}^{-1}$. During the leafed period, the spatial pattern of throughfall was highly temporal stable, which may result in spatial heterogeneity of soil moisture.
\end{abstract}

Keywords: Throughfall; Spatial variability; Temporal stability; Mixed evergreen-deciduous broadleaved forest; Shennongjia.

\section{INTRODUCTION}

Understory rainfall is composed of throughfall and stemflow, throughfall is the proportion of rainwater penetrating through canopy gaps (free throughfall) or dripping to the ground from the canopy (canopy drip), stemflow is the proportion that reaches the ground by funneling down the stems or trunks. In contrast to the former, stemflow is generally a smaller proportion, typically ranges between $0 \%$ and $10 \%$ of gross rainfall; it is a concentrated point source of water that reaches tree base (Van Stan and Gordon, 2018). Relatively speaking, the quantification of throughfall is substantial and therefore is an indispensable component in the watershed water budget (Dohnal et al., 2014; Nanko et al., 2016). At the stand scale, throughfall represents the largest volumetric component of gross precipitation, and usually constitutes more than $70 \%$ of incident rainfall (Loustau et al., 1992; Shi et al., 2010). Throughfall is directly related to the leaching and flushing processes of adsorbate of branches and leaves, and so it is considered as a critical transfer mechanism in biogeochemical cycles of forest ecosystems. Soil nutrient availability is influenced by the magnitude and chemical composition of throughfall (Rosier et al., 2015), areas where have more throughfall tend to have higher root density (Ford and Deans, 1978). As a consequence, throughfall is key input parameter in a diverse range of applications such as moisture recharging and nutrient exchange (Guswa and Spence, 2012). Because of the intermediate functions in hydrologic processes, throughfall has the potential to determine vegetation productivity through influencing available water and nutrients availability (Carlyle-Moses et al., 2014; Carnol and Bazgir, 2013). Improved knowledge of the spatial-temporal patterns of throughfall is, therefore, of crucial importance for eco-hydrological problems.

Interception loss constitutes a large proportion of regional evapotranspiration, direct in situ measurement of this rainfall fraction is challenging, therefore it is typically indirectly estimated by the difference between gross rainfall and the sum of throughfall and stemflow (Carlyle-Moses and Gash, 2011; Friesen et al., 2015). The estimation accuracy of interception loss in forest ecosystems, in most instances, is largely dependent on the measurement accuracy of gross rainfall and throughfall. Because of the unnegligible quantitative significance in the estimation of interception loss, any imprecision in observing throughfall would magnify the estimation error of interception loss, and thus in-depth knowledge on distribution patterns of throughfall becomes a precondition for studies on interception loss.

Canopy characteristics (phenoseason, canopy cover, stand density, leaf area index, crown length) (Park and Cameron, 2008; Siles et al., 2010; Zabret and Šraj, 2018), meteorological conditions (temperature, wind and vapour pressure deficit) (David et al., 2006; Dunkerley, 2000) and precipitation characteristics (rainfall amount, intensity and duration) (Levia and Frost, 2006; Zabret et al., 2018) usually exhibit considerable heterogeneity, which may increase the difficulty of understanding the throughfall distribution patterns in forest ecosystems. Of all the biotic and abiotic factors, canopy structure and architecture are deemed as the most important controls on throughfall heterogeneity. Certain leaf morphology and higher canopy epiphytic load, which can intercept and absorb substantial rainwater, results in higher throughfall variability (Park and Cameron, 2008; Van Stan and Pypker, 2015).

The arrangement of throughfall collectors is a strong influencing factor of throughfall heterogeneity. Loescher et al., (2002) didn't find any significant correlations between throughfall volumes and the distance to the nearest branch and leaf above the collector within a tropical rainforest in Costa Rica, but observed a weak relation between throughfall volumes and canopy cover. Herwitz (1987) and Sato et al. (2011) observed that collectors close to trunks were inclined to receive more throughfall in Australian tropical rainforest and Brazilian eucalyptus plantation, whereas Robson et al. (1994) reported an opposite tendency within a beech forest in southern England. 

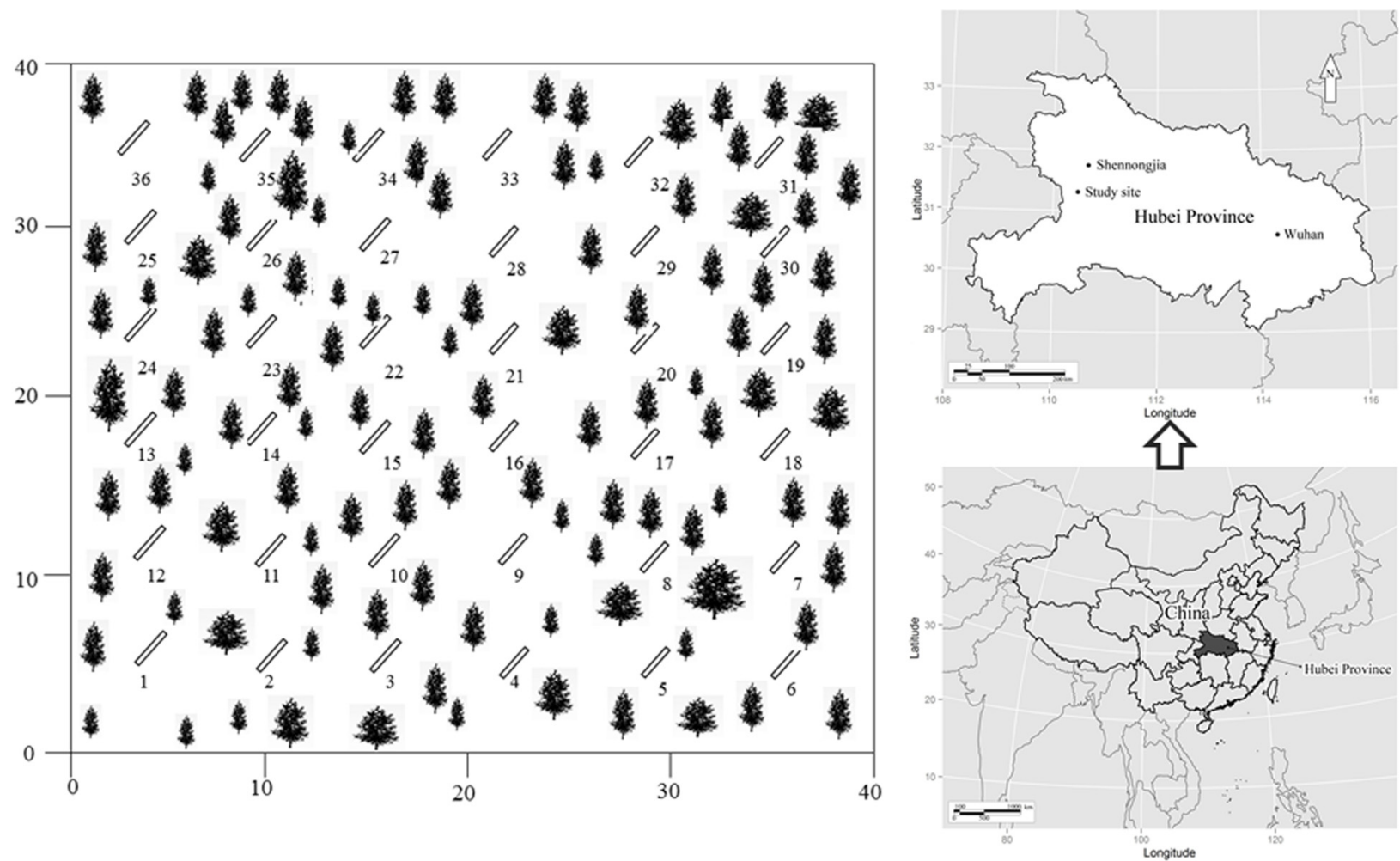

Fig. 1. Maps showing the location of the study area and throughfall collectors.

The mixed evergreen-deciduous broadleaved forest, a widely distributed forest type in the subtropical zone of China, is a complexity of evergreen broadleaved trees and deciduous broadleaved trees (Su et al., 2016a; 2016b). The stand structure is complex, the canopy composition is distinctive. Given its high biodiversity and small geographical range of the forest, the forest is among the most vulnerable ecosystems to climate change (Ge and Xie, 2017). Therefore, a better understanding of its rainfall distribution pattern is urgently required to predict the hydrological processes of the forest under climate change scenarios. Although stemflow and interception loss of the particular forest type have been described (Su et al., 2016a; 2016b), the throughfall patterns of the forest are not well known.

In the present paper, we investigate the spatio-temporal pattern of throughfall during leafed period in a mixed evergreendeciduous broadleaved forest. The objectives of the study are (1) to identify the magnitude of throughfall in the forest; (2) to investigate the driving factors of variation of throughfall; and (3) to estimate the spatial and temporal pattern of throughfall.

\section{MATERIALS AND METHODS Study area}

Shennongiia is located at Qinba Mountain, belonging to the "Daba Mountain evergreen forests" subcategory, which falls under the category of "Southwest China Temperate Forests" in the Global 200 categorization of world ecoregions (WWF, 2001). Based on its unique ecological system and intact preservation condition, Shennongjia can be seen as a typical representative of Daba Mountain evergreen forests, where the zonal vegetation is mixed evergreen-deciduous broadleaved forests. Shennongjia has preserved the most intact mixed evergreendeciduous broadleaved forests in China and even in the Northern Hemisphere, and therefore offers a typical example of the biological and ecological processes of the forests ( $\mathrm{Su}$ et al., 2016a; 2016b). These forests are the transitional zone between warm temperate deciduous broadleaved forests and subtropical evergreen broadleaved forests (Zhao et al., 2005).

Measurements of incident gross precipitation and throughfall were carried out during the leafed period of 2014 (May 1 to October 31) at the Shennongjia Biodiversity Research Station of Chinese Academy of Sciences, which is located in northwest Hubei at $110^{\circ} 28^{\prime} 27^{\prime \prime} \mathrm{E}, 31^{\circ} 18^{\prime} 23^{\prime \prime} \mathrm{N}$. The study site, located at the elevation of $1650 \mathrm{~m}$, is classified as typical subtropical monsoon climate. Mean monthly temperature varies from $1.2^{\circ} \mathrm{C}$ in January to $22.0^{\circ} \mathrm{C}$ in July, and mean annual air temperature (MAT) is $10.6^{\circ} \mathrm{C}$, and mean annual precipitation in the area between 2001 and 2010 is $1350 \mathrm{~mm}$ (Su et al., 2016b). According to the FAO classification, the soils at the site belong to Haplic Alisols.

The mixed evergreen-deciduous broadleaved forest, an extensively distributed forest type in Shennongjia, is the transitional type of evergreen broadleaved forest and deciduous broadleaved forest, which represents the typical forest types of the northern subtropical region of China. The study was completed in a flat $40 \mathrm{~m} \times 40 \mathrm{~m}$ plot whose characteristics are described in detail by $\mathrm{Su}$ et al. (2016a). The density of trees was $2407 \mathrm{ha}^{-1}$, the total basal area was $42.56 \mathrm{~m}^{2} \mathrm{ha}^{-1}$. The mean height and diameter at breast height were $8.0 \pm 2.2 \mathrm{~m}$ and $10.7 \pm 3.0 \mathrm{~cm}$, respectively. The dominant evergreen species included Cyclobalanopsis multinervis, Cyclobalanopsis oxyodon, Rhododendron hypoglaucum, Ilex pernyi, Lindera fragrans, the dominant deciduous species included Fagus engleriana, Quercus serrata var. brevipetiolata, Clethra cavalerei, Sorbus folgneri, Betula insignis, Dendrobenthamia japonica var. chinensis, and so on (Su et al., 2016b). Exact information of main tree species is provided in Table 1.

\section{Experimental design}

Compared with funnel-type collectors, trough-type collectors could considerably decrease the required sample sizes and 
Throughfall in a mixed evergreen-deciduous broadleaved forest

Table 1. Exact information of the main tree species in the study plot.

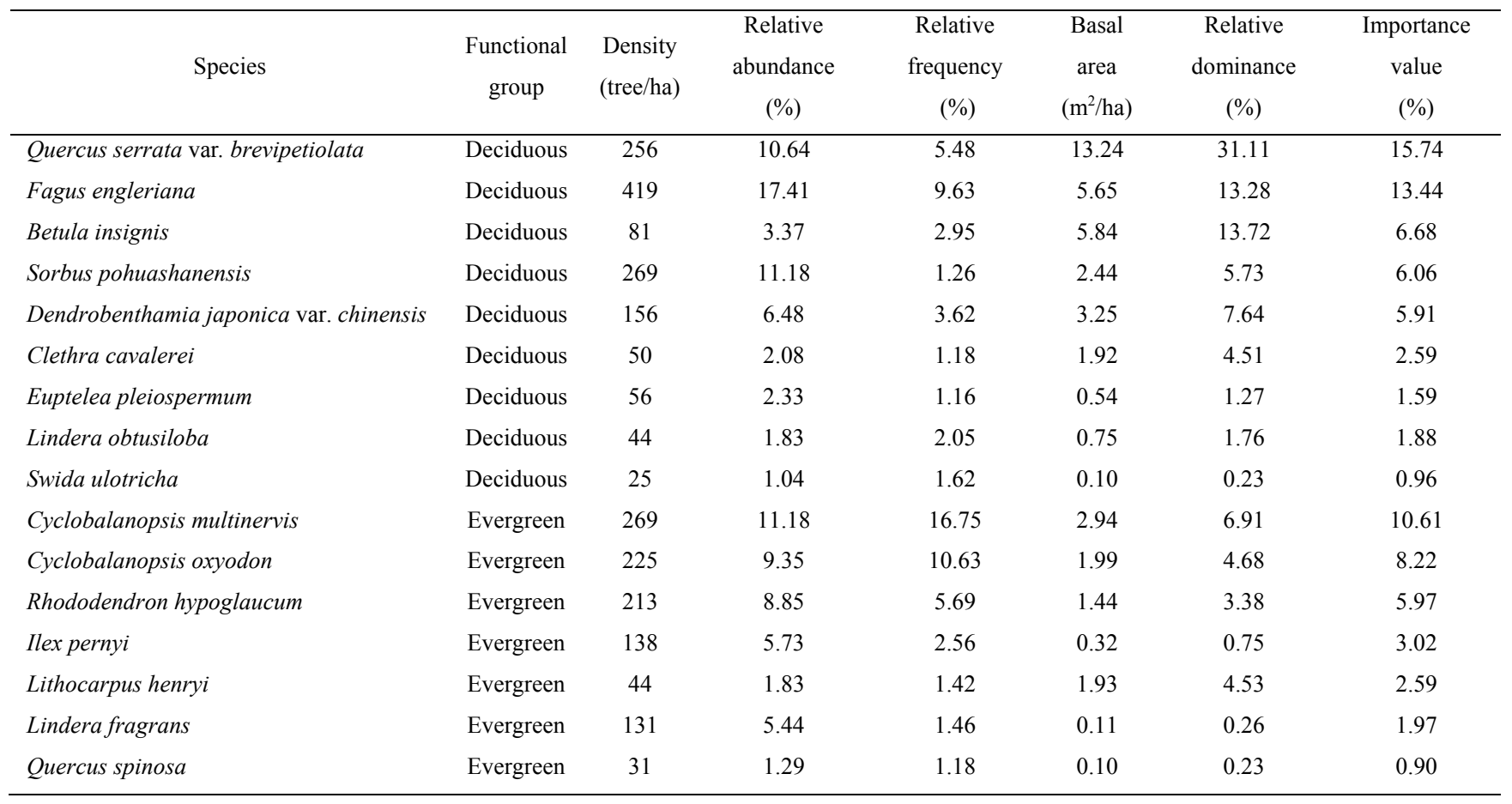

eliminate the sensitivity of the mean to outliers (Carlyle-Moses et al., 2014; Kostelnik et al., 1989; Zimmermann et al., 2010), so trough-type collectors were employed to measure gross precipitation and throughfall in the present study. Gross incident precipitation was collected in an open area, about $50 \mathrm{~m}$ away from the study site, using three trough-type collectors (the collectors were made of stainless steel with an opening area of $1 \mathrm{~m} \times 0.2 \mathrm{~m}$ ), where the collected rainwater would flow into a plastic pot through a small opening at the bottom of collectors. An automatic weather station (Model MAWS301, HydroMet ${ }^{\mathrm{TM}}$ system, Vaisala Corp., Finland) was situated approximately 500 $\mathrm{m}$ away from the study site, which could provide estimates of the duration and intensity of gross rainfall. The diameter of the rain gauge was $20 \mathrm{~cm}$, and the sensitivity of sensor was 0.1 $\mathrm{mm}$. The rainfall data were automatically collected and recorded at 30-min intervals.

Throughfall was measured with 36 collectors in accordance with the type of gross rainfall. These throughfall collectors were evenly distributed over the $40 \mathrm{~m} \times 40 \mathrm{~m}$ study plot in fixed positions (Figure 1), and they were cleaned at a frequency of every three days. All samples were immediately quantified after the cessation of a rain event or the next morning for events that occurred or extended into nighttime hours. To qualify as an incident rainfall event, an interval of at least $8 \mathrm{~h}$ without rain must be separated from adjacent rainfall events ( $\mathrm{Su}$ et al., 2016b). In this study, storms less than $1.5 \mathrm{~mm}$ were unable to generate measurable throughfall, and therefore storms larger than $1.5 \mathrm{~mm}$ were used to analyze throughfall. Although the automatic weather station (installed with a tipping bucket) was not very far from the study plot, the rainfall amount may vary between these two sites in some rainfall events because the mountainous climate may differ in very close distance apart. The automatic weather station monitored almost the same value with trough collectors in most cases, but the former was more accurate in measuring small rainfall events.

To determine leaf area index (LAI) and canopy cover, LAI2000 was taken above each of the 36 collectors under cloudy sky in the middle of the month from May to October in 2014.

We evaluated the temporal persistence of spatial patterns of throughfall using the methodology of Keim et al. (2005). Throughfall was quantified using standardized throughfall for each of the sample points using the formula as follows:

$T F S_{i}=\frac{T F_{i}-T F_{\text {mean }}}{S D}$

where $T F S_{i}$ is normalized throughfall at sampling point $i, T F_{i}$ is measured throughfall at sampling point $i, T F_{\text {mean }}$ is the mean throughfall for the rainfall event over all sampling points, and $S D$ is the standard deviation of throughfall for the rainfall event over all sampling points (Carlyle-Moses et al., 2014).

\section{RESULTS}

\section{LAI and canopy cover}

The variability of LAI was very small during the leafed period, LAI and canopy cover were biggest in August, and smallest in May, the mean LAI and canopy cover of August is 1.07 and 1.05 times of May, respectively. The shooting period of most of trees was April, the trees already had relative mature leaves and canopy in May and kept relatively stable during the leafed period.

\section{Gross rainfall}

During the leafed period from early May to the end of October 2014, a total of 48 events amounting to a cumulative depth of $1574.0 \mathrm{~mm}$ were recorded and snowfall was not detected. Mean incident rainfall event was $32.8 \mathrm{~mm}$ and varied from 0.1 $\mathrm{mm}$ to $207.7 \mathrm{~mm}$, mean rainfall intensity was $2.68 \mathrm{~mm} \mathrm{~h}^{-1}$ and ranged from $0.25 \mathrm{~mm} \mathrm{~h}^{-1}$ to $6.94 \mathrm{~mm} \mathrm{~h}^{-1}$. Of the 48 rainfall events, 8 events (with a total of $3.2 \mathrm{~mm}$ ) were too small to produce measurable throughfall, 40 events produced a total of $1335.1 \mathrm{~mm}$ throughfall, accounting for $84.8 \%$ of gross rainfall. 


\section{Variability of throughfall}

Throughfall rate against gross rainfall was showed in Figure 2 by means of box and whisker plots. 40 plots represented 40 rainfall events generating throughfall, and these events was ranked by rainfall amount. Throughfall rate increased with increasing gross rainfall amount, and gradually stabilize at larger rainfall events. Throughfall rate values greater than $100 \%$ were commonly monitored in larger rainfall events.

The coefficients of variation (CV) of throughfall were found to be highly variable during the leafed period, averaged $27.27 \%$, and varied from $6.82 \%$ to $72.72 \%$ for all rainfall events (Figure 3). Throughfall CV displayed a large variability for rainfall events $<25 \mathrm{~mm}$, and the throughfall $\mathrm{CV}$ became quasi-constant after reaching a gross rainfall input of $25 \mathrm{~mm}$.

There was a significant power function relationship between throughfall $\mathrm{CV}$ which was derived from all 36 collectors and rainfall intensity $\left(R^{2}=0.51, P<0.01\right)$ (Figure 4$)$. With increasing rainfall intensity, throughfall $\mathrm{CV}$ showed a trend of rapiddecreases and was relatively stable. It appeared that for rainfall intensity $>2 \mathrm{~mm} \mathrm{~h}^{-1}$ in magnitude, there was little variation in throughfall $\mathrm{CV}$.

\section{Temporal stability of spatial throughfall}

The normalized throughfall values were ranked by mean values in Figure 5 and the spatial distribution of throughfall was stable during the study period. Some collectors (e.g. 22, 33, 36, 27) gathered more throughfall than the mean normarlized throughfall, which would result in relative wet points on the forest floor. At the same time, there were also some collectors (e.g. $31,35,8,13$ ) receiving less throughfall than the mean normarlized throughfall, which would create dry points on the ground surface.

\section{DISCUSSION}

\section{Characteristics of throughfall}

The mean throughfall $\mathrm{CV}$ of the forest $(27.27 \%)$ was close to reported values in subtropical forests. Shen et al. (2012) reported that throughfall $\mathrm{CV}$ of secondary succession of evergreen broadleaved forest ranged from $25 \%$ to $39 \%$. However, the present value was higher than the findings in broadleaved forests, which were $18 \%$ for a deciduous broadleaved forest during leafed period (Staelens et al., 2006), 17\% for a broadleaved secondary forest (Deguchi et al., 2006), and $15.9 \% \sim 20.1 \%$ in a deciduous forest (Siegert et al., 2016). The higher throughfall $\mathrm{CV}$ in our study may be attributed to the dense canopy structure, which could provide more sheltered areas and drip points. Furthermore, the type and amount of throughfall collectors, rainfall and forest characteristics, sampling time scales of the aforementioned studies differed significantly with our study, making it difficult to directly compare the spatial variation of throughfall.

As indicated in the results, relationships between storm characteristics and both throughfall amount and variability are consistent with previous work (Carlyle-Moses et al., 2004; Loustau et al., 1992; Shinohara et al., 2010). Most of the rainwater in small rainfall events is portioned as canopy storage, and almost all throughfall is in the form of free throughfall, which originates from gross rainfall that passes directly through canopy gaps to the forest floor (Zimmermann et al., 2009). Throughfall variability responds dramatically to stand variables, larger canopy interaction usually result in greater spatial throughfall variability. After rainfall saturated canopy water storage capacity, throughfall variability remains quasi-constant with increasing rainfall. A possible explaination for this phenomenon is that the canopy has established quasi-permanent canopy drip zones where throughfall is concentrated, and canopy shelter zones where intercepted rainwater is either formed as interception loss or funneled to other part of the canopy or to the trunk and stem. For gross rainfall input exceeding the threshold required for the complete establishment of drip and shelter points, the spatial distribution of throughfall will be governed by these critical points, therefore the throughfall distribution patterns reach a steady state (Carlyle-Moses et al., 2014).

\section{Spatial distribution pattern of throughfall}

Previous throughfall studies have showed that throughfall patterns displayed a high temporal stability (Fan et al., 2015; Keim et al., 2005; Sato et al., 2011; Wullaert et al., 2009), this phenomenon was verified in our study (Figure 5), the range and variability of throughfall matched previous work. As docu-



Fig. 2. Box and whisker plots of throughfall rate against rainfall amount. The center line, bottom and top of the boxes represent the median, 25th and 75th percentiles, respectively. The whiskers represent the 5th and 95th percentiles. 


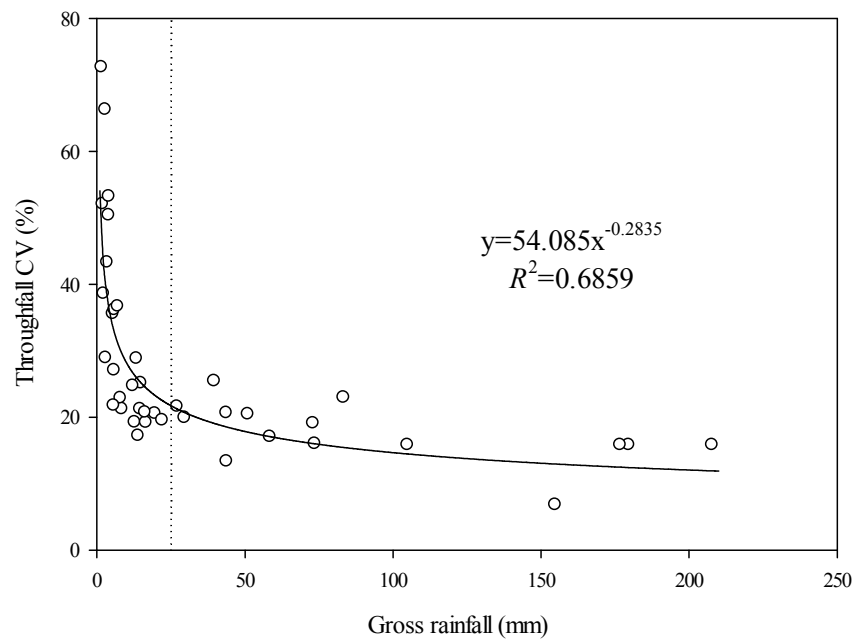

Fig. 3. Coefficient of variation of throughfall against gross rainfall.

mented in Figure 5, some collectors gathered significant more throughfall volumes than the mean, sometimes exceeded the gross rainfall. This could be explained by the fact that these collectors were located at the edge of canopy (Figure 1), the branches above the collectors were mostly down-facing, which seemed to play the role of funnelling and thus had convergence effects on throughfall volumes, consequently throughfall was concentrated at the canopy edge (Gerits et al., 2010; Fang et al., 2016; Fathizadeh et al., 2014; Staelens et al., 2006). However, inconsistent views on the relationship between the distance to the nearest trunk and throughfall volume have also been reported, Keim et al. (2005) found tree age was also a major determinant in throughfall distribution, wet gauges were close to trunks in a young conifer stand, while they were not obviously related to tree boles in an old conifer stand. The branches of young trees are straight and upward, which would transport rainwater to areas near the trunk like a funnel, whereas the relatively horizontal branches of old trees don't have this function. Besides tree age, rainfall amount may also lead to inconformity, André et al. (2011) observed that throughfall volumes would be greater at the crown periphery than adjacent to the trunks at the

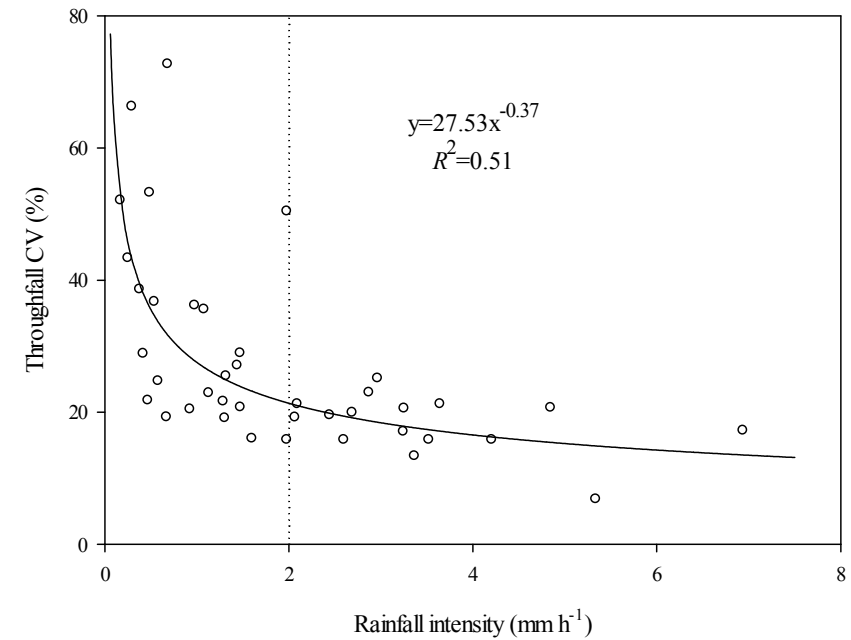

Fig. 4. The coefficient of variation of throughfall as a function of rainfall intensity.

early stages of rainfall events (c.a. $<5 \mathrm{~mm}$ ) and presented an opposite trend in large rainfall events. Free throughfall takes the majority of throughfall in small rainfall events, therefore areas under crown periphery could receive more water compared with those near the trunk. The funneling effect gradually increase with increasing rainfall amount, more throughfall would be gathered to trunks as canopy drips.

Spatial distribution of throughfall is greatly influenced by the spatial heterogeneity of canopy parameters. At the same time, we should not neglect the effect of meteorological parameters. Figure 3 and 4 showed that rainfall amount and intensity played crucial roles in modifying the spatial distribution of throughfall that reaches the forest floor. With the increase in rainfall amount and intensity, throughfall $\mathrm{CV}$ decreased by means of a negative power function, which is in agreement with the findings of Fan et al. (2015) in an exotic pine plantation of subtropical coastal Australia. Kato et al. (2013) found that throughfall increased with increasing distance to the nearest trunk in windless rainfall events, however, such a systematic throughfall pattern was not presented during windy conditions.

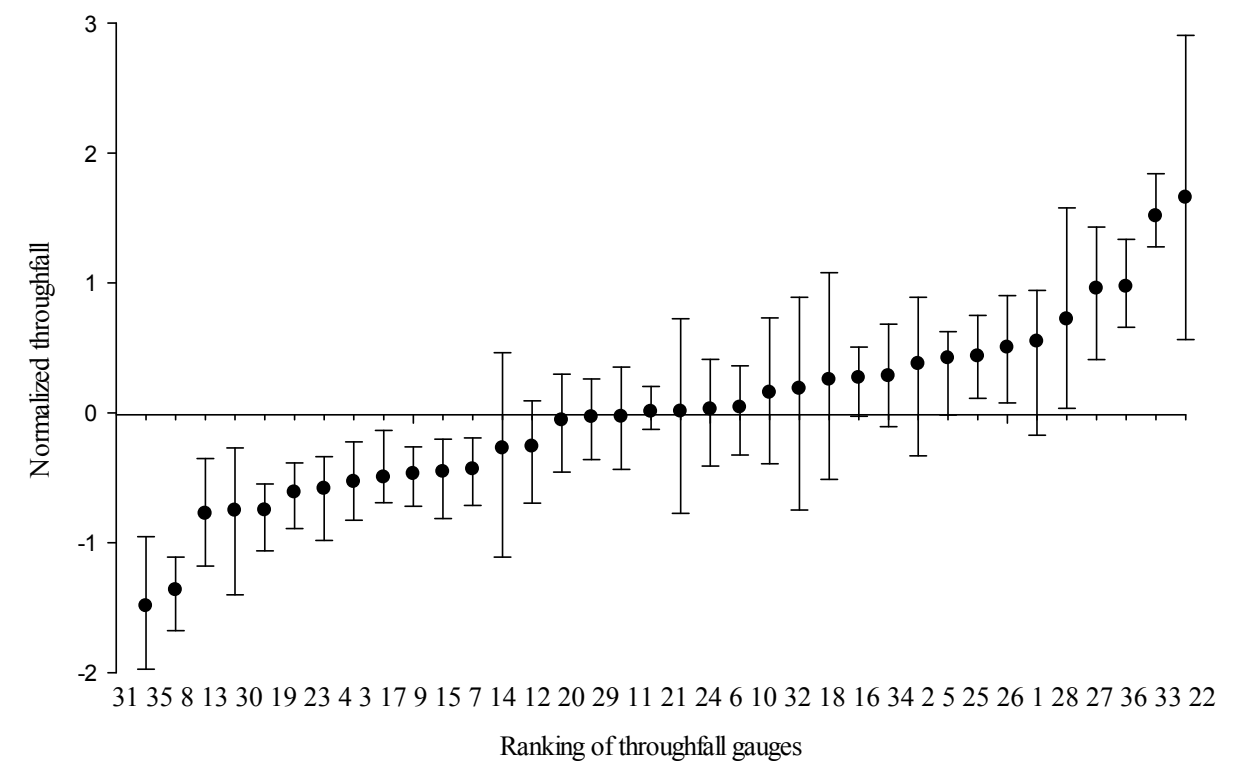

Fig. 5. Time stability plot of normalized throughfall. The upper and lower error whiskers represent the 75 th and 25 th percentiles, respectively. 
The location of collectors is a main determinant to obtaining a representative throughfall, previous studies have indicated that random relocation of collectors after each sampling could reduce the necessary collectors and not at the expense of misestimating throughfall (Carlyle-Moses et al., 2014; Holwerda et al., 2006; Kimmins, 1973; Ritter and Regalado, 2010). He et al. (2014) suggested that the locations of collectors should be placed at the sites of mean values of plant area index (PAI, the sum of all light-blocking elements of vegetation) due to position relationship between interception loss and PAI. As a consequence, if we want to reduce the sampling points as much as possible, we must identify locations where we have mean values of these canopy parameters before we arrange the sample. Because of the canopy may form stable "canopy drip zones" and "canopy shelter zones", the measured throughfall would be greatly influenced by extreme values if the capture area of gauges is very small (Zimmermann et al., 2010), therefore, we have to increase the capture area of gauges to reduce the impact of outliers.

\section{CONCLUSION}

In a diverse, structurally complex forest with heterogeneous throughfall patterns, the inter-event variability in stand-scale throughfall generation was greatly driven by rainfall size and intensity. The throughfall $\mathrm{CV}$ decreased significantly with increasing rainfall amount and intensity, and after rainfall amount reached $25 \mathrm{~mm}$ or rainfall intensity reached $2 \mathrm{~mm} \mathrm{~h}^{-1}$, when the canopy had formed stable regions of "canopy drip zones" and "canopy shelter zones", throughfall CV presented a stable trend. The spatial pattern of throughfall was highly temporal stable during the study period, which may lead to "wet zones" and "dry zones" in the forested land.

Acknowledgements. The study was completed with support from the Project of Chinese Academy of Sciences (No. QYZDY-SSW-SMC011), the Science and Technology Service Network Initiative of CAS (No. KFJ-SW-STS-167) and the National Natural Science Foundation of China (No. 41807158). The authors acknowledge the assistance provided by Kaiming Zhao, Hualan Qiu, Xianping Jia and Yongxiang Fu. We greatly appreciate the two anonymous reviewers for their constructive comments to improve this manuscript.

\section{REFERENCES}

André, F., Jonard, M., Jonard, F., Ponette, Q., 2011. Spatial and temporal patterns of throughfall volume in a deciduous mixed-species stand. Journal of Hydrology, 400, 244-254.

Carlyle-Moses, D.E., Laureano, J.S.F., Price, A.G., 2004. Throughfall and throughfall spatial variability in Madrean oak forest communities of northeastern Mexico. Journal of Hydrology, 297, 124-135.

Carlyle-Moses, D.E., Gash, J.H.C., 2011. Rainfall Interception Loss by Forest Canopies. In: Levia, D.F., Carlyle-Moses, D., Tanaka, T. (Eds.): Forest Hydrology and Biogeochemistry. Springer Netherlands, Heidelberg, pp. 407-423.

Carlyle-Moses, D.E., Lishman, C.E., McKee, A.J., 2014. A preliminary evaluation of throughfall sampling techniques in a mature coniferous forest. Journal of Forestry Research, 25, 407-413.

Carnol, M., Bazgir, M., 2013. Nutrient return to the forest floor through litter and throughfall under 7 forest species after conversion from Norway spruce. Forest Ecology and Management, 309, 66-75.
David, T.S., Gash, J.H.C., Valente, F., Pereira, J.S., Ferreira, M.I., David, J.S., 2006. Rainfall interception by an isolated evergreen oak tree in a Mediterranean savannah. Hydrological Processes, 20, 2713-2726.

Deguchi, A., Hattori, S., Park, HT., 2006. The influence of seasonal changes in canopy structure on interception loss: Application of the revised Gash model. Journal of Hydrology, 318, 80-102.

Dohnal, M., Černý. T., Votrubová, J., Tesař, M., 2014. Raifall interception and spatial variability of throughfall in spruce stand. Journal of Hydrology and Hydromechanics, 62, 277284.

Dunkerley, D., 2000. Measuring interception loss and canopy storage in dryland vegetation: a brief review and evaluation of available research strategies. Hydrological Processes, 14, 669-678.

Fan, J., Oestergaard, K.T., Guyot, A., Jensen, D.G., Lockington, D.A., 2015. Spatial variability of throughfall and stemflow in an exotic pine plantation of subtropical coastal Australia. Hydrological Processes, 29, 793-804.

Fang, S., Zhao, C., Jian, S., 2016. Spatial variability of throughfall in a Pinus tabulaeformis plantation forest in Loess Plateau, China. Scandinavian Journal of Forest Research, 31, 467-476.

Fathizadeh, O., Attarod, P., Keim, R.F., Stein, A., Amiri, G.Z., Darvishsefat, A.A., 2014. Spatial heterogeneity and temporal stability of throughfall under individual Quercus brantii trees. Hydrological Processes, 28, 1124-1136.

Ford, E.D., Deans, J.D., 1978. The effects of canopy structure on stemflow, throughfall and interception loss in a young Sitka spruce plantation. Journal of Applied Ecology, 15, 905-917.

Friesen, J., Lundquist, J., Van Stan, J.T., 2015. Evolution of forest precipitation water storage measurement methods. Hydrological Processes, 29, 2504-2520.

Ge, J., Xie, Z., 2017. Geographical and climatic gradients of evergreen versus deciduous broad-leaved tree species in subtropical China: Implications for the definition of the mixed forest. Ecology and Evolution, 7, 3636-3644.

Gerrits, A.M.J., Pfister, L., Savenije, H.H.G., 2010. Spatial and temporal variability of canopy and forest floor interception in a beech forest. Hydrological Processes, 24, 3011-3025.

Guswa, A.J., Spence, C.M., 2012. Effect of throughfall variability on recharge: application to hemlock and deciduous forests in western Massachusetts. Ecohydrology, 5, 563-574.

He, Z.B., Yang, J.J., Du, J., Zhao, W.Z., Liu, H., Chang, X.X., 2014. Spatial variability of canopy interception in a spruce forest of the semiarid mountain regions of China. Agricultural and Forest Meteorology, 188, 58-63.

Herwitz, S.R., 1987. Raindrop impact and water flow on the vegetative surfaces of trees and the effects on stemflow and throughfall generation. Earth Surface Processes and Landforms, 12, 425-432.

Holwerda, F., Scatena, F.N., Bruijnzeel, L.A., 2006. Throughfall in a Puerto Rican lower montane rain forest: A comparison of sampling strategies. Journal of Hydrology, 327, 592602.

Kato, H., Onda, Y., Nanko, K., Gomi, T., Yamanaka, T., Kawaguchi, S., 2013. Effect of canopy interception on spatial variability and isotopic composition of throughfall in Japanese cypress plantations. Journal of Hydrology, 504, 111.

Keim, R.F., Skaugset, A.E., Weiler, M., 2005. Temporal persistence of spatial patterns in throughfall. Journal of Hydrology, 314, 263-274. 
Kimmins, J.P., 1973. Some statistical aspects of sampling throughfall precipitation in nutrient cycling studies in British Columbian coastal forests. Ecology, 54, 1008-1019.

Kostelnik, K.M., Lynch, J.A., Grimm, J.W., Corbett, E.S., 1989. Sample size requirements for estimation of throughfall chemistry beneath a mixed hardwood forest. Journal of Environmental Quality, 18, 274-280.

Levia, D.F., Frost, E.E., 2006. Variability of throughfall volume and solute inputs in wooded ecosystems. Progress in Physical Geography, 30, 605-632.

Loescher, H.W., Powers, J.S., Oberbauer, S.F., 2002. Spatial variation of throughfall volume in an old-growth tropical wet forest, Costa Rica. Journal of Tropical Ecology, 18, 397-407.

Loustau, D., Berbigier, P., Granier, A., Moussa, F.E.H., 1992. Interception loss, throughfall and stemflow in a maritime pine stand. I. Variability of throughfall and stemflow beneath the pine canopy. Journal of Hydrology, 138, 449467.

Nanko, K., Hudson, SA., Levia, DF., 2016. Differences in throughfall drop size distributions in the presence and absence of foliage. Hydrological Science Journal, 61, 620 627.

Park, A., Cameron, J.L., 2008. The influence of canopy traits on throughfall and stemflow in five tropical trees growing in a Panamanian plantation. Forest Ecology and Management, 255, 1915-1925.

Ritter, A., Regalado, C.M., 2010. Investigating the random relocation of gauges below the canopy by means of numerical experiments. Agricultural and Forest Meteorology, 150, 1102-1114.

Robson, A.J., Neal, C., Ryland, G.P., Harrow, M., 1994. Spatial variations in throughfall chemistry at the small plot scale. Journal of Hydrology, 158, 107-122.

Rosier, C.L., Van Stan, J.T., Moore, L.D., Schrom, J.O.S., Wu, T., Reichard, J.S., Kan, J., 2015. Forest canopy structural controls over throughfall affect soil microbial community structure in an epiphyte-laden maritime oak stand. Ecohydrology, 8, 1459-1470.

Sato, A.M., Avelar, A.D., Netto, A.L.C., 2011. Spatial variability and temporal stability of throughfall in a eucalyptus plantation in the hilly lowlands of southeastern Brazil. Hydrological Processes, 25, 1910-1923.

Shen, H., Wang, X., Jiang, Y., You, W., 2012. Spatial variations of throughfall through secondary succession of evergreen broad-leaved forests in eastern China. Hydrological Processes, 26, 1739-1747.

Shi, Z., Wang, Y., Xu, L., Xiong, W., Yu, P., Gao, J., Zhang, L., 2010. Fraction of incident rainfall within the canopy of a pure stand of Pinus armandii with revised Gash model in the Liupan Mountains of China. Journal of Hydrology, 385, 4450.

Shinohara, Y., Onozawa, Y., Chiwa, M., Kume, T., Komatsu, H., Otsuki, K., 2010. Spatial variations in throughfall in a Moso bamboo forest: sampling design for the estimates of stand-scale throughfall. Hydrological Processes, 24, 253259.
Siegert, C.M., Levia, D.F., Hudson, S.A., Dowtin, A.L., Zhang, F., Mitchell, M.J., 2016. Small-scale topographic variability influences tree species distribution and canopy throughfall partitioning in a temperate deciduous forest. Forest Ecology and Management, 359, 109-117.

Siles, P., Vaast, P., Dreyer, E., Harmand, J.M., 2010. Rainfall partitioning into throughfall, stemflow and interception loss in a coffee (Coffea arabica L.) monoculture compared to an agroforestry system with Inga densiflora. Journal of Hydrology, 395, 39-48.

Staelens, J., De Schrijver, A., Verheyen, K., Verhoest, N.E.C., 2006. Spatial variability and temporal stability of throughfall water under a dominant beech (Fagus sylvatica L.) tree in relationship to canopy cover. Journal of Hydrology, 330, 651-662.

Su, L., Xu, W., Zhao, C., Xie, Z., Ju, H., 2016a. Inter- and intra-specific variation in stemflow for evergreen species and deciduous tree species in a subtropical forest. Journal of Hydrology, 537, 1-9.

Su, L., Zhao, C., Xu, W., Xie, Z.Q., 2016b. Modelling interception loss using the revised Gash model: a case study in a mixed evergreen-deciduous broadleaved forest in China. Ecohydrology, 9, 1580-1589.

Van Stan, J.T., Gordon, D.A., 2018. Mini-review: Stemflow as a resource limitation to near-stem soils. Frontier in Plant Science, 9, 248.

Van Stan, J.T., Pypker, T.G., 2015. A review and evaluation of forest canopy epiphyte roles in the partitioning and chemical alteration of precipitation. Science of the Total Environment, 536, 813-824.

World Wide Fund for Nature (WWF), 2001. The Global 200Blueprint for a Living Planet. On the WWF website at www.panda.org/livingplanet/global200_new.cfm.

Wullaert, H., Pohlert, T., Boy, J., Manosalvas, C.V., Wilcke, W., 2009. Spatial throughfall heterogeneity in a montane rain forest in Ecuador: Extent, temporal stability and drivers. Journal of Hydrology, 377, 71-79.

Zabret, K., Šraj, M., 2018. Spatial variability of throughfall under single birth and pine tree canopies. Acta Hydrotechnica, 31, 1-20.

Zabret, K., Rakovec, J., Šraj, M., 2018. Influence of meteorological variables on rainfall partitioning for deciduous and coniferous tree species in urban area. Journal of Hydrology, 558, 29-41.

Zhao, C.M., Chen, W.L., Tian, Z.Q., Xie, Z.Q., 2005. Altitudinal pattern of plant species diversity in Shennongjia Mountains, Central China. Journal of Integrative Plant Biology, 47, 1431-1449.

Zimmermann, A., Zimmermann, B., Elsenbeer, H., 2009. Rainfall redistribution in a tropical forest: Spatial and temporal patterns. Water Resources Research, 45, W11413.

Zimmermann, B., Zimmermann, A., Lark, R.M., Elsenbeer., H., 2010. Sampling procedures for throughfall monitoring: A simulation study. Water Resources Research, 46, W01503.

Received 27 February 2018 Accepted 30 May 2018 